\title{
Identifying The Centripetal And Centrifugal Forces Through Khap Panchayats In Haryana-An Analysis
}

\author{
Satpal Singh*, Dalbir Singh** \\ * Haryana Adminstrative Services, Haryana India \\ **Associate Prof., Deptt. of Geography, Pt.NRS Govt. College Rohtak, Haryana (India) 124001
}

\begin{abstract}
Centripetal' and 'Centrifugal' are the forces where Centripetal force tends to produce integrating force and the 'Centrifugal force' tends to produce disintegrating force from functioning of 'Khap Panchayats. It has been observed that the existence of these forces have always been playing a 'vital role' for determine the behaviour of 'Khap Panchayts' from time to time. This study examines the continuity and changing situations as well as constructive and destructive role, played by these 'Khap Panchayats' in Haryana. On the basis of an empirical study, carried out on 200 respondents from rural and urban areas indicate a varied response as tested by the t-test. On the basis of findings of the study which give its Strength, Weakness, Opportunity and Threats (SWOT) analysis of 'Khap Panchats' in Haryana. It also includes some of positive suggestions which are essential to ameliorating the functioning Haryana.
\end{abstract}

Keywords: Centripetalforce, centrifugalforce, Khap Panchayat, vital role, SWOT analysis

\section{Introduction:}

The 'Centripetal' and 'Centrifugal' forces in social geography as put forward by Azazudin Ahmad (1999)in his writings on 'Social geography', indicates integrating forces which determine the behavior of social and communal harmony. These two forces are often used in Physics; denote the cementing forces and 'diversifying forces' in the 'moving objects'. Meaning thereby; these are the forces which determine the behavior of social group or groups. These two forces determine the human behavior of the work force engaged in constructive or destructive works. As a result of these forces also determine the outcome of social harmony or disharmony, depend upon how these forces work. Khap Panchayat is an ancient, democratic and socially sanctioned institution of Haryana. The historic past indicates that the 'Khap Panchayats' have been playing a vital role and indulged in such things which may threats to its social values. The Khap Panchayats play a significant role for raising the voice against discrimination, injustice and disharmony during pre and postindependence periods. Now there is continuity and change in their actions and reactions in the rural society in Haryana (Inder Singh, 2009)Now these Khap Panchayats are producing 'centripetal' and 'centrifugal' forces for integrating and disintegrating forces for mollifying the conflicting situation as well as creating disharmony in the rural society.

The initial unit of organizational hierarchy of Khap Panchayat is the village which spread over an area. It begins with the family and keeps on organizing numerous of families, known as 'Thola'. The formation of many 'Tholas', constitute a 'Pana' or 'Patti'. Village is formed by many Panas. And further the group of different villages form a 'Tapa', 'Thamba' 'Chaugama', 'Pachgama', 'Athgama', 'Chaubisi' and 'Araha', is known as 'Tholedar'. The elder of the village is known as Pradhan. There is system of inherent appointment system of 'Khap Panchayat is still temporary in nature. Presently the headquarters of 'SarvaKhap Panchayat' is located at the village Soram in the district Mujjafernagar in Uttar Pradesh.

Khap Panchayats has a long historic past. It is one of oldest institution, evolved through different successive periods. Initially, establishment of 'Khap Panchayat' was began with 701 B.C. 


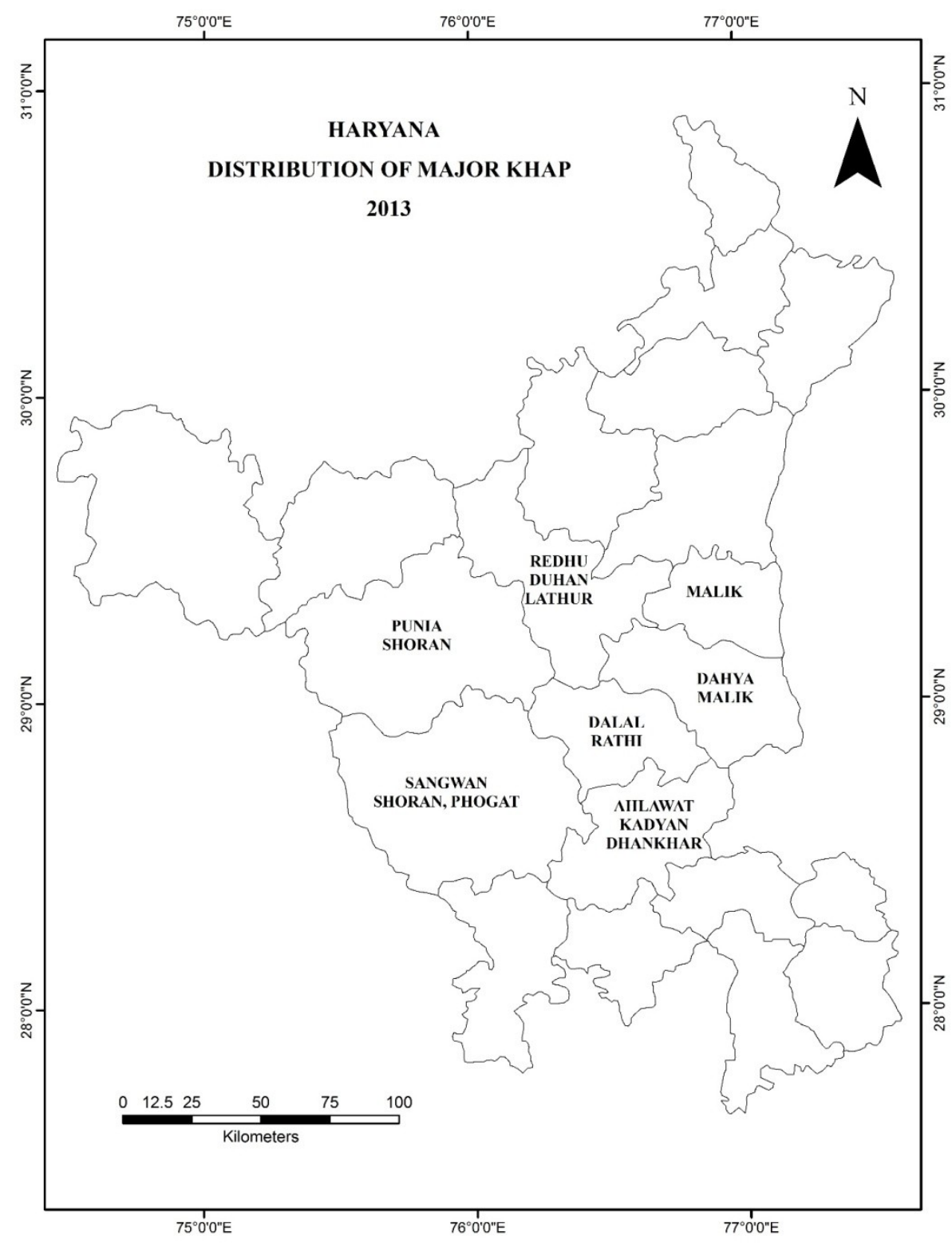

HISTORIC PAST OF KHAP PANCHAYATS:Captain DilipS Singh, 1988) in the period of 'Samrat Harsh Vardhana. The meaning of 'Sarav Khap Panchayat 'means 'Sarva $+\mathrm{Kh}+$ Aap. Meaning thereby, the water-which is purity, Panch means unbiased, truthful, and practical and justice? And a person who is well acquainted with the subject matter is known as 'Panch.It is a group of five people? According to historical record the first meeting of 'Sarav Khap Panchayat was held in 1184 AD. The participants in this meeting were Mehar chand Tyagi, Hada Singh Ahir, Mohan Singh Kayath, Mat Ram Gujjar and Dewal Singh Saini.In 1287 AD, the 'Sarve Khap Panchayat' there were 60,000 Jats, 25,000 Gujjar and Deval Singh Saini who participated in this conference. During the 1857AD Revolution, the 'Sarva Khap Panchayat' had played a vital role for ruling out necessity of 'Akhara' in every village. It was also made mandatory for the youth within the age-group of 18-40, to recruit in their force and they have been trained accordingly. They have fought against the 'Royal Army' and the'Despotism' imposed by the king 'Kutubuddin Aibak, who used to impose 'Zazia'and subsequently he had to unconditionally compromise in the year 1194 AD.In the year 1199 AD, under the leadership of Harpal Rana, a meeting of 'Khap Panchayats' was held at Tikri village and resolved for construct the 'Akhara' and imparted battle training for the youths within the age group of 18-40 years. In $1287 \mathrm{AD}$, another meeting was hold under the leadership of ch. Mastpal and condemned the 'Zazia' imposed by the king. In 1498 AD, CH. Devpal Rana organized a 'Khap Panchayat' at Nirpura village and passed a resolution against King Taimurlang. The other associates were Jagmohan Gujjar and Dhahia Balmiki.who were appointed as chief and deputyChief of the force which they have constituted. Under the leadership of Ch. Shoshal Senapati and Ch. Ram Kala, who was deputy 
'Senapati' and Ch. Ram kala, who was deputy Sena pati in the formed force for sending back all the foreigners immediately? According to 'Mistak Mirasi' Swami Vijranand, the Guru of Sawami Dyanand addressed," The life of slave is worse than a dog' and motivated to take an active participate in the freedom struggle. After the Independence struggle during 1857 AD the British were succeeded to split up of 'Sarve Khap Panchayats'. The western part of the 'Khap Panchayats' subsequently shifted to Punjab region, which is presently Haryana.

\section{Khap Panchayatin Post-Independence Scenario:}

The role of Khap Panchayats has been remarkably appreciated by the scholars, belong to different streams. The 'Khap Panchayats' have been rising socio-economic and political issues from time to time. The pressing problems which includes prevention of drinking habits among the villagers, female foeticide problem and dowry system in the villages are some of vital issues raised by the 'Khap Panchayats.' In order to put check on dowry system, a vital role played by the 'Khap Panchayats' a conference was held in the year 1950 at the village Beri in the Jhajjar district, where the rules framed by the 'Khap Panchayats' were to be followed by everyone, barring any caste, creed and religion (Chaudhry,D.R. 2006). Another burning issue of female foeticide problem was highlighted by the Bibipur Gram Panchayats of Jind district of Haryana. This Gram Panchayat invited all 'Sarv Khap Panchayats and made an extensive discussion on this burning issue of North West region of India. Similarly, the problem of land acquisition by the state has become another burning issue for the suffering farmers. The 'Khap Panchayats' are acting as a 'great pressure group' for protecting the peasants' rights. They are now raising voice against inadequate compensation for their fertile lands and wrong policy of state land-acquisition in the state.

Since formation of Haryana as a separate state which has experienced a rapid growth of urbanization and industrialization has given rise to urbanism in the countryside in Haryana. As a result a modernization process is influencing the rural youth to a considerable extent. It is because of rapid growth of rural income and education. As a result a confronting situation has been developed with the norms and changing attitude of youth of Haryana state. There are numerous of instances, when the rural youth got married within their own 'Gotras' or married within the villagers where it was a 'Taboo' due to practice of 'Bhaichara '(brotherhood) between the two villages. In this situation, 'honour killing' honorific epithet for brutal murder of females for violating sexual norms set in patriarchal social set up (Chaudhry,D.R.2010) the 'Khap Panchayat' is an endogamous clan institution, now largely a 'Jat outlet' around Delhi. Its concept of brotherhoods had to several taboos which have under serious strain these days. It is a matter of serious thinking and no 'panacea' seems to control this menace of the rural society.

Today, the traditional rural structure is cracking up under the impact of modernism, leading to increase intimacy between the two sexes in a village. So long as these relations remained wraps, there is no problem. However, when it takes a shape of marriage, as a result it leads to erode of social mores which invites barbaric edicts. There has been upsurge in such killing in the 'Khap belt' around Delhi of late, capped by the murder of two cousin sisters along with one's husband hailing from village Wazirpur in Delhi state. The fear of killing makes couples flee. Over three dozen couple of Haryana is now under police protection. The problem can be sorted out through mutual dialogue, keeping in view the need for harmonious blend of tradition and modernity, so essential for awards advancement of society. However, this does not seem to be possible in the changing scenario. Khap ideologies often refer to Vedic culture in support of their contention. There was a traditional concept of 'Swamvar' in the Vedic period permitting girls to choose their spouses, as it was depicted in 'Rig Veda' indicate a liberal attitude and open them the suffocating social set-up Khap custodians wish to perpetuate. The Arya Samaj has been the most powerful reform movement in the 'Khap belt.' Swami Dayan and, its founder, Characterize choice marriage as 'Uttam' in his book 'Satyarth Prakash.' However, choice marriage invites the wrath of 'Khap leaders' who mostly owe allegiance to the revered Swami.

The 'centrifugal force' has been developed when the 'Khap Panchayat' had a legal confrontation with some of judgments awarding exemplary punishment to the accused for murdering a couple in Haryana for marrying within the same 'Gotra' has provided to be threshold. This confronting situation has given rise to agitating for an amendment in the 'Hindu Marriage Act' imposing a ban on the same 'Gotra' and same village marriage. The 'Khaps' are several centuries have portrayed the violation of marital taboos considered as 'sinful' which deserve stringent punishment, generating in turn, a culture of intolerance. The demarcated line between intolerance and violence is thin. The families with the girls, shown a deviant behavior, become a target of taught and clammy make their life unbearable in their village itself. It is because of they carry the stigma of social dishonor which is shed off only through the alchemy of murder, which is executed as divine duty and killers feel proud of it.

\section{Methods and Material:}

In order to analyses the views on 'Khap Panchats's functioning a structured questionnaire has been administered on the respondents belong to various socio-economic and cultural background. In This context, 
total 200 respondents (100 from rural and 100 from urban areas) have been taken for the study. In order to carry out the study, an area sampling and stratified sampling of the respondents which includes castes, age, sex and other family schedule such as size of land-holding, occupation, cultural-interaction, educational level etc. have been taken into consideration. The empirical study based on some of respondents from rural and urban areas indicate a varied response on identifying the 'centripetal 'and 'centrifugal' force through 'Khap Panchayats' in Haryana. For testing the Hypothesis, the t-test technique has been employed for drawing the desired objectives.

For t-test $=$

Where

$$
\frac{\bar{x}-\bar{y}}{s \times \sqrt{\frac{1}{\mathrm{n}_{1}}+\frac{1}{\mathrm{n}_{2}}}} \sim t \mathrm{n}_{1}+\mathrm{n}_{2}-2
$$

$$
\begin{aligned}
& \bar{x}=\frac{1}{\mathrm{n}_{1}} \sum \mathrm{x}, \bar{y}=\frac{1}{\mathrm{n}_{2}} \sum \mathrm{y} \\
& s^{2}=\frac{1}{\mathrm{n}_{1}+\mathrm{n}_{2}-2}\left[\sum(x+\bar{x})^{2}+\sum(y+\bar{y})^{2}\right]
\end{aligned}
$$

is an unbiased estimate of the respond variance based on both the samples of respondents By comparing the computed value oft with the tabulated value of $t$ for $n_{1}+n_{2}-2$ and at desired level of significance.

\section{Objectives of the Study:}

* The study is aimed at identifying the 'centripetal' and 'centrifugal' forces through 'Khap Panchayat's Functioning in Haryana state

* To examine the strength, weakness, opportunity and threat of 'Khap Panchayats' in Haryana;

* To test the Hypothesis of the difference between the response of the respondents from rural and urban areas;

* To suggest some of mitigating measures to make the 'Khap Panchayats' more effective in the changing scenario.

\section{The Study Area:}

The study area is confined to Haryana state. In this context, the respondents from rural and urban areas have been considered for the study. In order to carry out the study the 'Khap Panchayats dominated areas, some of khap Panchayat dominated areas have been considered. These areas which includes Jhajjar, Rohtak, Jind, Bhiwani, Panipat, Sonepat, Hissar, Sirsa. All these districts are characterized by the distinguish 'Khap Panchayat of Haryana. The respondents who include the people of rural and urban areas of these varied 'Khap' dominance districts. In this context the other non-Khap Panchayats districts such as Rewari, Ambala,Mahendergarh, Kurukshetra, Mewat, Faridabad, Palwal, Fatehabad, Yamunanagar and Panchkula have been considered too.

\section{Results and Discussion:}

On the basis of empirical study, carried out on 200 respondents (100 respondents from rural areas and 100 from urban areas) have responded their views on 'centripetal' and 'centrifugal' forces which have been affecting the behavior of the respondents of different socio-economic background of the resident of Haryana. All these respondents have been tabulated as follows:

\begin{tabular}{|c|c|c|c|c|c|c|c|c|c|c|c|c|c|}
\hline \multirow[t]{2}{*}{$\begin{array}{l}\text { Sr. } \\
\text { No }\end{array}$} & \multirow[t]{2}{*}{ Response of Respondents } & \multicolumn{2}{|c|}{ Agree } & \multicolumn{2}{|c|}{$\begin{array}{l}\text { Strongly } \\
\text { agreed }\end{array}$} & \multicolumn{2}{|c|}{ No opinion } & \multicolumn{2}{|c|}{ Disagreed } & \multicolumn{2}{|c|}{$\begin{array}{l}\text { Strongly } \\
\text { disagreed }\end{array}$} & \multicolumn{2}{|l|}{ Total } \\
\hline & & $\mathrm{R}$ & $\mathrm{U}$ & $\mathrm{R}$ & $\mathrm{U}$ & $\mathrm{R}$ & $\mathrm{U}$ & $\mathrm{R}$ & $\mathrm{U}$ & $\mathrm{R}$ & $\mathrm{U}$ & $\mathrm{R}$ & $\mathrm{U}$ \\
\hline 1. & $\begin{array}{l}\text { Constructive/ destructive } \\
\text { role of Khap Panchayats }\end{array}$ & $\begin{array}{l}30 \\
(30)\end{array}$ & $\begin{array}{l}25 \\
(25)\end{array}$ & $\begin{array}{l}12 \\
(12)\end{array}$ & $\begin{array}{l}5 \\
(5)\end{array}$ & $\begin{array}{l}10 \\
(10)\end{array}$ & $\begin{array}{l}3 \\
(3)\end{array}$ & $\begin{array}{l}10 \\
(10)\end{array}$ & $\begin{array}{l}17 \\
(17)\end{array}$ & $\begin{array}{l}38 \\
(38)\end{array}$ & $\begin{array}{l}50 \\
(50)\end{array}$ & $\begin{array}{l}100 \\
(100)\end{array}$ & $\begin{array}{l}100 \\
(100)\end{array}$ \\
\hline 2. & $\begin{array}{l}\text { Khap Panchayats are } \\
\text { changing acc. to time }\end{array}$ & $\begin{array}{l}22 \\
(22)\end{array}$ & $\begin{array}{l}10 \\
(10)\end{array}$ & $\begin{array}{l}8 \\
(8)\end{array}$ & $\begin{array}{l}7 \\
(7)\end{array}$ & $\begin{array}{l}3 \\
(3)\end{array}$ & $\begin{array}{l}4 \\
(4)\end{array}$ & $\begin{array}{l}7 \\
(7)\end{array}$ & $\begin{array}{l}6 \\
(6)\end{array}$ & $\begin{array}{l}60 \\
(60)\end{array}$ & $\begin{array}{l}73 \\
(73)\end{array}$ & $\begin{array}{l}100 \\
(100)\end{array}$ & $\begin{array}{l}100 \\
(100)\end{array}$ \\
\hline 3. & $\begin{array}{l}\text { Khap Panchayats } \\
\text { decisions are rational and } \\
\text { judicious }\end{array}$ & $\begin{array}{l}10 \\
(10)\end{array}$ & $\begin{array}{l}7 \\
(7)\end{array}$ & $\begin{array}{l}5 \\
(5)\end{array}$ & $\begin{array}{l}6 \\
(6)\end{array}$ & $\begin{array}{l}5 \\
(5)\end{array}$ & $\begin{array}{l}7 \\
(7)\end{array}$ & $\begin{array}{l}20 \\
(20)\end{array}$ & $\begin{array}{l}25 \\
(25)\end{array}$ & $\begin{array}{l}60 \\
(60)\end{array}$ & $\begin{array}{l}55 \\
(55)\end{array}$ & $\begin{array}{l}100 \\
(100)\end{array}$ & $\begin{array}{l}100 \\
(100)\end{array}$ \\
\hline
\end{tabular}

\section{Attitude of the Respondents towards 'Centripetal' and 'Centrifugal' Forces Produced by'Khap Panchayats' in Haryana}




\begin{tabular}{|c|c|c|c|c|c|c|c|c|c|c|c|c|c|}
\hline 4. & $\begin{array}{l}\text { Khap Panchayats } \\
\text { decisions are accepted by } \\
\text { majority of the people of } \\
\text { different areas }\end{array}$ & $\begin{array}{l}40 \\
(40)\end{array}$ & $\begin{array}{l}52 \\
(52)\end{array}$ & $\begin{array}{l}10 \\
(10)\end{array}$ & $\begin{array}{l}8 \\
(8)\end{array}$ & $\begin{array}{l}5 \\
(5)\end{array}$ & $\begin{array}{l}4 \\
(4)\end{array}$ & $\begin{array}{l}15 \\
(15)\end{array}$ & $\begin{array}{l}12 \\
(12)\end{array}$ & $\begin{array}{l}30 \\
(30)\end{array}$ & $\begin{array}{l}24 \\
(24)\end{array}$ & $\begin{array}{l}100 \\
(100)\end{array}$ & $\begin{array}{l}100 \\
(100)\end{array}$ \\
\hline 5. & $\begin{array}{l}\text { Khap Panchayat's } \\
\text { decisions are sanctioned } \\
\text { by social institutions like } \\
\text { caste, family, relation etc. }\end{array}$ & $\begin{array}{l}60 \\
(60)\end{array}$ & $\begin{array}{l}63 \\
(63)\end{array}$ & $\begin{array}{l}10 \\
(10)\end{array}$ & $\begin{array}{l}7 \\
(7)\end{array}$ & $\begin{array}{l}5 \\
(5)\end{array}$ & $\begin{array}{l}5 \\
(5)\end{array}$ & $\begin{array}{l}10 \\
(10)\end{array}$ & $\begin{array}{l}12 \\
(12)\end{array}$ & $\begin{array}{l}30 \\
(30)\end{array}$ & $\begin{array}{l}13 \\
(13)\end{array}$ & $\begin{array}{l}100 \\
(100)\end{array}$ & $\begin{array}{l}100 \\
(100)\end{array}$ \\
\hline 6. & $\begin{array}{l}\text { Khap Panchayats able to } \\
\text { produce 'cementing/ } \\
\text { diversifying force' for } \\
\text { communal harmony }\end{array}$ & $\begin{array}{l}50 \\
(50)\end{array}$ & $\begin{array}{l}42 \\
(42)\end{array}$ & $\begin{array}{l}10 \\
(10)\end{array}$ & $\begin{array}{l}5 \\
(5)\end{array}$ & $\begin{array}{l}5 \\
(5)\end{array}$ & $\begin{array}{l}8 \\
(8)\end{array}$ & $\begin{array}{l}5 \\
(5)\end{array}$ & $\begin{array}{l}4 \\
(4)\end{array}$ & $\begin{array}{l}30 \\
(30)\end{array}$ & $\begin{array}{l}41 \\
(41)\end{array}$ & $\begin{array}{l}100 \\
(100)\end{array}$ & $\begin{array}{l}100 \\
(100)\end{array}$ \\
\hline 7. & $\begin{array}{l}\text { Khap Panchayat's } \\
\text { decisions } \\
\text { challenges in the country }\end{array}$ & $\begin{array}{l}30 \\
(30)\end{array}$ & $\begin{array}{l}26 \\
(26)\end{array}$ & $\begin{array}{l}10 \\
(10)\end{array}$ & $\begin{array}{l}14 \\
(14)\end{array}$ & $\begin{array}{l}4 \\
(4)\end{array}$ & $\begin{array}{l}5 \\
(5)\end{array}$ & $\begin{array}{l}6 \\
(6)\end{array}$ & $\begin{array}{l}7 \\
\text { (7) }\end{array}$ & $\begin{array}{l}50 \\
(50)\end{array}$ & $\begin{array}{l}48 \\
(48)\end{array}$ & $\begin{array}{l}100 \\
(100)\end{array}$ & $\begin{array}{l}100 \\
(100)\end{array}$ \\
\hline 8. & $\begin{array}{l}\text { Khap Panchayat's role } \\
\text { for social reforms in rural } \\
\text { society }\end{array}$ & $\begin{array}{l}45 \\
(45)\end{array}$ & $\begin{array}{l}42 \\
(42)\end{array}$ & $\begin{array}{l}15 \\
(15)\end{array}$ & $\begin{array}{l}18 \\
(18)\end{array}$ & $\begin{array}{l}3 \\
(3)\end{array}$ & $\begin{array}{l}5 \\
(5)\end{array}$ & $\begin{array}{l}7 \\
(7)\end{array}$ & $\begin{array}{l}7 \\
\text { (7) }\end{array}$ & $\begin{array}{l}30 \\
(30)\end{array}$ & $\begin{array}{l}21 \\
(21)\end{array}$ & $\begin{array}{l}100 \\
(100)\end{array}$ & $\begin{array}{l}100 \\
(100)\end{array}$ \\
\hline 9. & $\begin{array}{l}\text { Tendency of two regional } \\
\text { Khap Panchayat's views } \\
\text { are uniform in rural } \\
\text { society }\end{array}$ & $\begin{array}{l}45 \\
(45)\end{array}$ & $\begin{array}{l}34 \\
(34)\end{array}$ & $\begin{array}{l}15 \\
(15)\end{array}$ & $\begin{array}{l}19 \\
(19)\end{array}$ & $\begin{array}{l}3 \\
(3)\end{array}$ & $\begin{array}{l}5 \\
(5)\end{array}$ & $\begin{array}{l}7 \\
(7)\end{array}$ & $\begin{array}{l}9 \\
(9)\end{array}$ & $\begin{array}{l}30 \\
(30)\end{array}$ & $\begin{array}{l}33 \\
(33)\end{array}$ & $\begin{array}{l}100 \\
(100)\end{array}$ & $\begin{array}{l}100 \\
(100)\end{array}$ \\
\hline 10. & $\begin{array}{l}\text { In the Khap Panchayats, } \\
\text { there is single caste } \\
\text { domination or they } \\
\text { includes other too }\end{array}$ & $\begin{array}{l}55 \\
(55)\end{array}$ & $\begin{array}{l}51 \\
(51)\end{array}$ & $\begin{array}{l}45 \\
(45)\end{array}$ & $\begin{array}{l}49 \\
(49)\end{array}$ & - & - & - & - & - & - & $\begin{array}{l}100 \\
(100)\end{array}$ & $\begin{array}{l}100 \\
(100)\end{array}$ \\
\hline 11. & $\begin{array}{l}\text { Khap Panchayats produ- } \\
\text { cing a spirit for } \\
\text { movement for social } \\
\text { reforms }\end{array}$ & $\begin{array}{l}44 \\
(44)\end{array}$ & $\begin{array}{l}41 \\
(41)\end{array}$ & $\begin{array}{l}16 \\
(16)\end{array}$ & $\begin{array}{l}19 \\
(19)\end{array}$ & $\begin{array}{l}9 \\
\text { (9) }\end{array}$ & $\begin{array}{l}10 \\
(10 \\
)\end{array}$ & $\begin{array}{l}21 \\
(21)\end{array}$ & $\begin{array}{l}17 \\
(17)\end{array}$ & $\begin{array}{l}10 \\
(10)\end{array}$ & $\begin{array}{l}13 \\
(13)\end{array}$ & $\begin{array}{l}100 \\
(100)\end{array}$ & $\begin{array}{l}100 \\
(100)\end{array}$ \\
\hline 12. & $\begin{array}{l}\text { Rate of success of Khap } \\
\text { Panchayats for removing } \\
\text { prejudices against social } \\
\text { evil }\end{array}$ & $\begin{array}{l}26 \\
(26)\end{array}$ & $\begin{array}{l}29 \\
(29)\end{array}$ & $\begin{array}{l}11 \\
(11)\end{array}$ & $\begin{array}{l}7 \\
(7)\end{array}$ & $\begin{array}{l}11 \\
(11)\end{array}$ & $\begin{array}{l}11 \\
(11 \\
)\end{array}$ & $\begin{array}{l}12 \\
(12)\end{array}$ & $\begin{array}{l}25 \\
(25)\end{array}$ & $\begin{array}{l}40 \\
(40)\end{array}$ & $\begin{array}{l}25 \\
(25)\end{array}$ & $\begin{array}{l}100 \\
(100)\end{array}$ & $\begin{array}{l}100 \\
(100)\end{array}$ \\
\hline 13. & $\begin{array}{l}\text { Khap Panchayat's } \\
\text { attitude towards sex } \\
\text { discrimination }\end{array}$ & $\begin{array}{l}60 \\
(60)\end{array}$ & $\begin{array}{l}58 \\
(58)\end{array}$ & $\begin{array}{l}20 \\
(20)\end{array}$ & $\begin{array}{l}19 \\
(19)\end{array}$ & $\begin{array}{l}2 \\
(2)\end{array}$ & $\begin{array}{l}3 \\
(3)\end{array}$ & $\begin{array}{l}9 \\
(9)\end{array}$ & $\begin{array}{l}11 \\
(11)\end{array}$ & $\begin{array}{l}9 \\
(9)\end{array}$ & $\begin{array}{l}9 \\
(9)\end{array}$ & $\begin{array}{l}100 \\
(100)\end{array}$ & $\begin{array}{l}100 \\
(100)\end{array}$ \\
\hline 14. & $\begin{array}{l}\text { Capacity of Khap } \\
\text { Panchayats taking for } \\
\text { decision making }\end{array}$ & $\begin{array}{l}15 \\
(15)\end{array}$ & $\begin{array}{l}14 \\
(14)\end{array}$ & $\begin{array}{l}11 \\
(11)\end{array}$ & $\begin{array}{l}10 \\
(10)\end{array}$ & $\begin{array}{l}14 \\
(14)\end{array}$ & $\begin{array}{l}11 \\
(11 \\
)\end{array}$ & $\begin{array}{l}33 \\
(33)\end{array}$ & $\begin{array}{l}37 \\
(37)\end{array}$ & $\begin{array}{l}27 \\
(27)\end{array}$ & $\begin{array}{l}28 \\
(28)\end{array}$ & $\begin{array}{l}100 \\
(100)\end{array}$ & $\begin{array}{l}100 \\
(100)\end{array}$ \\
\hline 15. & $\begin{array}{l}\text { Degree of influence by } \\
\text { the local people on Khap } \\
\text { Panchayats }\end{array}$ & $\begin{array}{l}11 \\
(11)\end{array}$ & $\begin{array}{l}14 \\
(14)\end{array}$ & $\begin{array}{l}5 \\
(5)\end{array}$ & $\begin{array}{l}7 \\
(7)\end{array}$ & $\begin{array}{l}5 \\
(5)\end{array}$ & $\begin{array}{l}8 \\
(8)\end{array}$ & $\begin{array}{l}58 \\
(58)\end{array}$ & $\begin{array}{l}49 \\
(49)\end{array}$ & $\begin{array}{l}21 \\
(21)\end{array}$ & $\begin{array}{l}22 \\
(22)\end{array}$ & $\begin{array}{l}100 \\
(100)\end{array}$ & $\begin{array}{l}100 \\
(100)\end{array}$ \\
\hline
\end{tabular}

Source: Field Survey,*Percentages are given in brackets. R- Rural,U- Urban

Keeping in view tabulated figures of the respondents belong to rural and urban areas of Haryana, who have responded on 'centripetal' and 'centrifugal' forces which have been producing by the 'Khap Panchayats,' the following discussion has been highlighted as follows:

- The constructive role of 'Khap Panchayats' which is one of indicator of 'centripetal Force' and indicates a varied response as responded by the rural urban respondents. In this context, only one-third of the respondents, belong to rural and urban areas are agreed and strongly agreed on this perception. On the contrary, 44percent respondents have shown their opinion by 'strongly disagree on this 'perception' asit indicates a varied response, given by the rural and urban respondents. In this Context, the 10 per cent respondents from rural and only 3 per cent respondents from urban areas have been failed to form any opinion on this 'perception'. It indicates a considerable difference between the respondents of rural and urban areas. On the other hand, the destructive role of 'Khap Panchayat' which is also one of indicators of 'Centrifugal force' also indicates a varied response from rural and urban areas. In this context, a considerable number of respondents from rural and urban areas, have been agreed and strongly disagreed (38 per cent each from rural and urban areas respectively) with this view.

- With regarding to 'Khap Panchayat' which is changing in accordance with changing time, we observe that the majority of the respondents have not been 'agreed' with this 'perception. Only one third of the respondents from rural areas agrees and strongly agrees on this perception. As far as urban respondents are concerned, it is quite obvious from the tabulated figures, only 10 per cent of the respondents are in favour of this 'perception,' but majority of the respondents (60 to 73Per cent) have not been agreed rather 'strongly disagreed' with this perception.

- In connection with 'judicious and rationality' of 'Khap Panchayat's decision, we observe that the respondents, ranges from 10 to 15 percent, who are agreed on this 'perception. The rural and urban respondents more or less same. On the contrary, 75 to 80 percent of the respondents have not been agreed 
rather shown their attitude with strongly disagree even on this perception. In this context, only few respondents have failed to form any opinion on this 'perception'.

- In connection with acceptability of Khap Panchayat decision by the majority of the people, it has been observed from the tabulated data, which indicate a acceptance by the over 50 per cent of the respondents, belong to rural and urban areas. On the other hand, over 50 per cent of the respondents have not been agreed rather they have even strongly disagreed with this 'perception'. Only few respondents have not been responded at all from rural and urban areas.

- On the view of Khap Panchayat's decisions are sanctioned by the social institutions like family, caste and religion, it is quite clear from the tabulated data which indicate a objective thinking on this issue. Over 70 per cent of the respondents from rural and urban areas indicate more or less uniform opinion on this issue. On the other hand, there is considerable difference in opinion of the respondents, belong to rural and urban areas for not agreeing on this issue. There is 10 to 20 percent difference have been found in their opinion.

- On the view point of 'capacity' for producing 'cementing force' for communal harmony, the majority of the respondents ranging from 50 to 60 per cent, indicate their views by agreeing or strongly agreed on this issue. Only 25 to 30 per cent of the respondents from rural and urban background indicate their views by saying disagree/strongly disagreed on this perception.

- On the view of 'challenging the decisions of 'Khap Panchayats' in the courts has been supported by more or less one third of the respondents, belong to rural and urban areas of Haryana. On the other hand, over 50 per cent of the respondents from rural and urban areas have not been agreed on it rather disagreed too. Only few respondents have failed to form any opinion on this issue.

- In connection with the perception of Khap Panchayat' s role in social reforms in rural society, we may observe that the majority of the respondents which account 50 to 60 per cent, indicate their views on agreeing and strongly agreeing with this 'perception'. On the other hand, one third of the respondents have shown their 'disagree' or strongly disagree' attitude on this perception. Only 10 per cent of the respondents from rural and urban areas have failed to form any opinion on this issue.

- On the view point of 'uniformity of views for two regional Khap Panchayat', as indicated by 50 to 60 per cent of the respondents from the rural and urban areas of Haryana, have shown their attitude by 'agreeing and strongly agreeing' with this perception. On the other hand, 30 to 35 per cent of the respondents, have 'disagreed' and 'strongly disagreed' on this issue. Lastly more or less 10 per cent of the respondents have failed to form any opinion on this issue.

- On the view point of dominance of single caste in the Khap Panchayat, it is quite obvious from the tabulated figures which indicate 100 per cent dominated by the single caste. The rural and urban areas attitude more or less same, as indicated by the respondents of varied socio economic background.

- On the view of producing spirit for movement for social reforms, it is quite obvious from the tabulated proportionate figures which indicate that the respondents over 50 per cent from the rural and urban areas indicate their views on agreeing with this 'perception'. According to these respondents, the Khap Panchayats have been playing a vital role to give an impetus to various movements for providing safeguard to interests of the people belong to various strata of rural society. On the other hand, over one third of the respondents have indicated their views by disagreeing with this 'perception'. Only 10 per cent of the respondents belong to different rural and urban background, have failed to form any opinion in this regards.

- In connection with taking the views on the success rate of Khap Panchayat for removing prejudices against social evils, it has been observed from the tabulated proportionate figures, which indicate a considerable variability. It is obvious from the tabulated figures that the respondents belong to rural and urban areas indicate more or less same views as indicated by one third of respondents. They are either agreed or strongly agreed. On the other hand, over 50 per cent of the respondents from rural and urban areas have not been agreed on this perception. There are one tenth of the respondents, who have failed to form any opinion on this issue.

- Analyzing the Khap Panchayat's views on 'sex discrimination', for this it is quite obvious from the proportionate figures, as indicated by rural and urban respondents, which ranges from 70 to 80 per cents, highlights the fact that the Khap Panchayats are only male dominating groups. Only one tenth of the respondents have disagreed on this issue, but they deny from an active participation of women in the 'Khap Panchayats'.

- In connection with the views on 'capacity of Khap Panchayats for taking decision on some of crucial matters', it has been observed that the respondents belong to rural and urban areas have either 'disagreed' or 'strongly disagreed' as indicated by the 60 per cent of the respondents. On the other hand, only 15 per cent of the respondents have shown their positive attitude by agreeing with this 'perception'. The same numbers of respondents have failed to form any opinion on this issue. 
- Lastly, the view on the perception of influence of local people on the 'decision making' capacity of 'Khap Panchayats', it has been observed that there is least probability of any type of pressure, which is considered for decision making on any crucial matter, as indicated by the 70 per cent of the respondents. In this connection, a considerable variability has also been noticed in view point of rural and urban respondents. There is 10 per cent variability has been found in both the respondents on this issue. In this context, only 5 to 8 per cent of the respondents belong to rural and urban areas, have not been shown any opinion on this 'perception'.

Hence, it is obvious from the empirical study, carried out of 200 respondents, belong to different rural and urban areas of Haryana and indicate their objective and subjective views on different 'perception 'of" Khap Panchayats, which have been working from time to time in Haryana In context to views on 'centrifugal force', produce by 'Khap Panchayats' in Haryana, various qualitative and quantitative parameters of 'centrifugal force' indicate that the 'Khap Panchayats' have been producing some of 'centrifugal force' which has given rise to create a disharmony in the rural communities. On the view 'Destructive role of Khap Panchayats, there are 38 per cent of the respondents from rural and urban areas, have been 'disagreed' and 'strongly disagreed' on this 'perception'. On the other hand, 45 percent of the respondents from rural and urban areas have not been agreed on this perception. Whereas 5 to 11 per cent of the respondents have failed to form any opinion on this issue.

\section{Testing of Hypothesis:}

Keeping in view varied responses of 200 respondents belong to various strata of rural and urban society; indicate an objective and subjective responses on various 'perception'. In this situation, a hypothesis has been developed that the response of rural and urban community are more or less same. This hypothesis has been tested by t-test technique as follows:

\begin{tabular}{lcccr}
$\begin{array}{l}\text { Suppose } \\
\text { Sample }\end{array}$ & $\begin{array}{c}\text { Null Hypothesis } \\
\text { Rural }\end{array}$ & $\begin{array}{c}\mathrm{Ho}=\mu_{1}=\mu_{2} \\
\text { Urban }\end{array}$ & Calculated Value & Tabulated Value \\
\hline Mean & 79.33 & 43.80 & 2.46 & \\
\hline S.D & 8.34 & 6.69 & \\
\hline
\end{tabular}

In this equation, the calculated value is more than the tabulated value. Therefore, the hypothesis is rejected. Hence, the significant evidence that the 'composite response' of all the response, responded by the rural and urban community, indicate a considerable variability in their views on identifying the 'centripetal' and 'centrifugal force' through 'Khap Panchayats' in Haryana.

SWOT Analysis of Khap Panchayat: On the basis of observed data, as indicated by the study, carried out in rural as well as urban areas of Haryana, worked out the SWOT analysis as follows:

Strength: The Khap Panchayat has a glorious historic past. The Khap Panchayats especially 'Sarv Khap Panchayats' have been playing a significant role since its formation year 1184 AD. It has a significant contribution in accelerating the national movements during different successive periods. These 'Khap Panchayats' have been producing a 'centripetal force' which have been proved conducive to generate cementing force for the people from different walk of life in different contemporary societies. Historic past of 'Khap Panchayats' indicate their success rate in success of peasant's movements, labour movement and socio-economic and political reforms for the deprived sections of society. It has been acting as a great 'pressure group' for collective bargaining on various issues, raised by the 'Khap Panchayats' in Haryana.

Weakness: In order to analysis the weakness of 'Khap Panchayats', we review the outcome of actions and reactions of 'Khap Panchayats' on various socio-economic and political issues which have not been tackled by the 'Khap Panchayats' from time to time. Its rigidity on 'Gotras' issue, dominance of single caste, no active participation of other castes, excessive participation of illiterate or semi illiterate people, taking extreme steps for 'honor killing' of youth for getting married within the same gotras, irrational thought dominance, no change in accordance with time, absence of legal entity and existence of unorganized institutional support, are some of weakness of 'Khap Panchayats' in Haryana.

Opportunity: The 'Khap Panchayats' had some of good opportunities in past, when it would have been better to modify its 'organizational behavior in accordance with the change of time. As a result, the conflicting situation has been rising from time to time. Keeping in view the changing scenario, it become imperative to review the functioning of 'Khap Panchayats' and should be modified with modernization of society. There is an opportunity to remove a 'cultural lag' which is continued till now. It is expected to pave the way to produce more 'centripetal' force which will ensure to render a 'cementing' force for communal harmony in Haryana.

Threat: The'Khap Panchayats' which have been some of threats, associated with their functioning itself. The 'Khap Panchayat's organizational behavior which has been threat to the rational human being, legal entity, threat on the 
spirit of human justice, threat on the communal harmony, threat to human rights, dominance of 'despotism' within the 'Khap Panchayats', probability of creating disharmony are some of threats of 'Khap Panchayats'.

Keeping in view the SWOT analysis of 'Khap Panchayats', it require some of reforms, which can be proved conducive to make the 'Khap Panchayats' more effective to 'human problem solving' measure rather than problem creating. It require legal entity with an institutional support from different social, economic and political institutions so that the 'Khap Panchayats' may produce 'centripetal force' for social stability in the countryside of Haryana. As far the head of 'Khap Panchayats' is concerned, it also require a 'periodic elections' so that a right person may provide 'good leadership' and guidelines for 'constructive' Khap Panchayats in Haryana. They should follow the status of old age institution which has been played a constructive role in the medieval times. The Khap Panchayat should continue with some of modifications in accordance with changing scenario. There should be a formal membership of a Khap, so that the identify of Khap Panchayat may be recognized universally, not only in Haryana, but in the whole country too.

\section{Conclusion:}

Khap Panchayats have been producing 'centripetal and centrifugal' force in its functioning for raising the socio economic and political issues in the rural areas of Haryana. Now these Khap Panchayats have become a nuisance, rather than solving any problem of different problematic areas. In this context, this study throws an adequate light on identifying the 'centripetal and centrifugal' force in the Khap Panchayats. The surveys conducted from the respondents from different districts of Haryana, indicate a considerable variability in their attitudes of the people belong to rural and urban areas. This difference has also been tested by t-test. The SWOT analysis of Khap Panchayats also indicates its strength, weakness, opportunity and threat to this unorganized social institution, working in rural society of Haryana.

The ends of the justice would be met if the contemplated law brings into its ambit all those who glorify killings along with the actual perpetrators of the crime and infringement of any of the rights of a citizen guaranteed under the Indian constitution. The enactment of a stringent law and its effectiveness is very essential. A collective psychosis has been spawned by the Khap Panchayats over the issue of tradition and there is need to build a vibrant civil society, fragile in the khap built at present to usher in an inclusive and human social set up. Only the 'centripetal force' is to be generated through functioning of 'Khap Panchayats' which may ensure to lead a social stability for the people, living in thousands villages in Haryana.

\section{References:}

[1]. Arya, Nihal Singh (1991), 'Serv Khap ka Rashtria Prakashan, Saini Printers, New Delhi.

[2]. Azaddi, Ahmad (1999), 'Social Geography' Rawat Publications, Jaipur

[3]. Chaudhry, D.R. (2012), 'Who are Political Parties Silent on Khap?' These so called Panchayats must be banned, retrieved on Dec.5 from www.tribuneindia.com/2009/20090816/edit.htm\#1

[4]. Choudhry, D.R. (2006) 'Khap Panchyats out of Tune with the Time' The Tribune, January 28, Chandigarh

[5]. Choudhry, D.R. (2010) 'Killing in the Khap belt- Imperative need to build a vibrant Civil Society' The Tribune, Sept. 26.

[6]. Chaudhry, Prem (2001), 'Caste Panchayats and the Policy of Marriage in Haryana: Enforcing Kinship and Territorial Exogamy' the International Sociology Journal, pp. 7-14.

[7]. Desai, A.R. (1969), 'Rural Sociology in India', Popular Prakashan, Delhi

[8]. Devi Sunil and Shaveta Begra (2011), 'Khap Panchayats in Haryana' Punjab University Research Journal (Arts) Vol.XXXVIII Nos 1\&2 April-Oct. Chandigarh

[9]. Gupta, S.C. (2009), 'Fundamentalof Statistics', Himalayan Publishing House, Delhi.

[10]. Harris, K.D.(1974), 'The Geography of Crime and Justice', Mc Grew Hill, New York.

[11]. Raj Lakshmi, T.K. (2005), 'Caste in Justice', Frontline, May 6, p.51, Chennai.

[12]. Saini, Ravinder Singh (2009), 'Gotra Row: Sarva Khap revises Exile Verdict', The Tribune, New Delhi, Aug. 10.

[13]. Sarvari Satvir, (2009), 'Khap Panchayat not just a Social Force, but Political too', The Hindustan Times, Sept.25.

[14]. Sarwari, Satvir (2009), 'Gotra Row: Sarva Khap for Mild Punishment', The Hindu, Aug.10.

[15]. Sarwari, Satvir (2009), 'Jat Meet for Change in Hindu Marriage Act', The Hindustan Times, New Delhi, Aug.10.

[16]. Singh Ranbir (2010), 'The Need to Tam the Khap Panchayats', Economic and Political Weekly, May 22, Vol. XLV, No 21.

[17]. Singh, Dalip (1988), 'Jaat Veero Ka Itihas, Arya Printing Press, Rohtak

[18]. Singh, Inder (2009), 'Khap Panchayat and Social Harmony’, Journal of Punjab Geographer, October.

[19]. Singh, Yoginder (1973), 'Modernization of Indian Tradition', Thomson Press, Delhi.

[20]. Srinivas, M.N.(1986), 'Social Structure', Hindustan Publishing Corporation, Delhi

[21]. Staff Reporter (2009), 'Khap Panchayats Reign Supreme in Haryana Villages' The Hindu, July 26.

[22]. The Tribune (2011), 'Who Rules Haryana? The Law or the Khap? Retrieved on March, 13, from www.tribuneindia.com/2009/20090725/edit.htm\#1 